\title{
Risk Preferences and Misconduct: Evidence from Politicians
}

\section{Citation}

Minor, Dylan. "Risk Preferences and Misconduct: Evidence from Politicians." Harvard Business School Working Paper, No. 16-073, January 2016.

\section{Permanent link}

http://nrs.harvard.edu/urn-3:HUL.InstRepos:24009684

\section{Terms of Use}

This article was downloaded from Harvard University's DASH repository, and is made available under the terms and conditions applicable to Other Posted Material, as set forth at http:// nrs.harvard.edu/urn-3:HUL.InstRepos:dash.current.terms-of-use\#LAA

\section{Share Your Story}

The Harvard community has made this article openly available.

Please share how this access benefits you. Submit a story. 


$$
\text { H A R VAR D B US INESS SCHOOL }
$$

Risk Preferences and Misconduct: Evidence from Politicians

Dylan Minor

Working Paper 16-073 


\title{
Risk Preferences and Misconduct: Evidence from Politicians
}

\author{
Dylan Minor
}

Harvard Business School

Working Paper 16-073 


\title{
Risk Preferences and Misconduct: Evidence from Politicians
}

\author{
Dylan Minor \\ Harvard Business School
}

December, 2015

\begin{abstract}
When seeking new leaders, business and government organizations alike often need individuals that are less risk averse, or even risk-seeking, in order to improve performance. However, individuals amenable to increased risktaking may be more likely to engage in misconduct. To study this issue, we explore US political scandals and the implicated politicians' portfolio choices. We find that a politician allocating all of her portfolio to risky investments has double the odds of being involved in a political sandal compared to a politician allocating all of her portfolio to safe investments. This suggests that those who are more willing to take risks in their personal finances are also more likely to engage in misconduct. We validate portfolio choice as a measure of risk preferences by correlating actual high-stakes investment choices (average $\$ 700,000$ US) to conventional laboratory lottery choices (average $\$ 51$ US) of wealthy investors.
\end{abstract}


"The biggest risk is not taking any risk...In a world changing really quickly, the only strategy that is guaranteed to fail is not taking risks."

Mark Zuckerberg, CEO Facebook

Risk-taking is widely understood to be a vital aspect of leadership, as it can generate immense value. Entrepreneurs, who are famous (or infamous) for their risk-taking qualities, are vital for economic growth; Schumpeter (1942) would go so far as to say that they are "essential to capitalism" (Hathaway and Litan [2014]). Similarly, in the workplace managers are central to firm growth and also tend to be risk-takers (March and Shapira [1987] and Koudstaal et al. [2015]). In politics, politicians seeking to spark positive change through new or updated policy are often risk-takers. As John W. Gardner, former Secretary of Health, Education, and Welfare under President Lyndon Johnson, so ostentatiously stated:

"What leaders have to remember is that somewhere under the somnolent surface is the creature that builds civilizations, the dreamer of dreams, the risk taker."

But risk-taking can also eradicate value. The Great Recession is replete with examples of risk-taking destroying value, often through misconduct. While managers that are less risk-averse are more likely to take risks that lead to successful outcomes (MacCrimmon et al. [1986] and MacCrimmon and Wehrung [1990]), they may also be more likely to engage in misconduct. Indeed, in other settings, it has been found that otherwise desirable behaviors (e.g., creativity and high productivity) can lead to greater misconduct (Gino and Ariely [2012] and Housman and Minor [2015]). Thus, this paper asks a simple question: might those who have a greater appetite for risk be more likely to cause harm through misconduct? Our research finds an affirmative answer.

Although risk-taking and misconduct occurs in many settings, one setting that provides an excellent laboratory in which to explore the potential link between risk preferences and misconduct is politicians. Due to the highly public lives that politicians lead, misconduct is common and observable, as is risk-taking. As a motivating example, consider former U.S. Representative Tom Delay, who engaged in some risktaking in the 1970s. He became an entrepreneur after his graduation from college 
and drastically increased the value of the pest control firm he purchased. He used his success as a springboard into politics where, amidst myriad other scandals, he was ultimately convicted of money-laundering. ${ }^{1}$ Consider Hillary Clinton's history as another example: in 1978, she engaged in some highly speculative commodities investment trading, and ended up turning $\$ 1,000$ into an impressive $\$ 100,000$ over the course of only ten months. However, she was later involved in a plethora of scandals: from the Whitewater scandal to the mass termination of White House Travel Office employees ("Travelgate") to her personal email use. ${ }^{2}$

The form of risk-taking that we study is financial risk-taking. Some scholars suggest that risk-taking is domain dependent (e.g., Weber and Milliman (1997) and Weber, Blais, and Betz (2002)). For example, some of those willing to take the physical risk of skydiving may not be willing to engage in financial risk-taking, only investing conservatively (e.g., only investing in US Treasury Bills). Others have argued that risk preferences globally predict behavior (e.g., Borgahns et al. [1995] and Dohmen [2011]). It could be that people hedge risk-taking in one domain by means of choices made in another domain. For example, someone engaging in misconduct might simultaneously invest conservatively to ensure that funds are available for a legal defense in the event of being indicted or charged for their misconduct. Nonetheless, we find that politicians with an increased likelihood of financial risk-taking are substantially more likely to become involved in political scandals of all types.

To measure propensity for financial risk-taking, we reconstruct politicians' actual portfolio allocations between safe and risky investments. The notion that portfolio allocation choices reflect an investor's fundamental risk preferences has been a standard assumption in finance for some time (e.g., Markowitz [1952], Merton [1969], Samuelson [1969], and Arrow [1971]). Although, the method has been successfully applied in the laboratory to elicit risk preferences (e.g., see Charness et al. [2013]), it has not very often been used in the field.

To further justify our use of portfolio allocations to identify risk preferences, we

\footnotetext{
${ }^{1}$ https://en.wikipedia.org/wiki/Tom_DeLay

${ }^{2}$ http://www.theatlantic.com/politics/archive/2015/10/tracking-the-clinton-controversiesfrom-whitewater-to-benghazi/396182/
} 
conduct a field experiment with wealthy investors. In particular, we conduct an incentivized multiple price list (MPL) method of elicitation, in the style of Holt and Laury (2002). We then link the investors' MPL choices to their portfolio allocation choices, finding that the former is an excellent predictor of the latter. Past work has shown the worth of determining the precise absolute level of risk aversion, as this level can change dramatically across stakes (e.g., Holt and Laury [2002] and Bombardini and Trebbi [2012]). However, we find that the relative level of risk aversion for the small-stakes MPL incentivized lottery choices (average value of $\$ 51$ ) consistently predicts high-stakes portfolio choices (average $\$ 700,000$ portfolio values).

While some work has explored risk-taking in response to environmental stimuli (e.g., Higins [1997] and Gino and Margolis [2011]), this paper focuses on risk-taking as arising from a stable personal characteristic (Kogan and Wallach [1964], Weber et al. [2002], Borgans et al. [2008], Dohman [2011], and Sahm [2012]). Though early theory work suggests that risk attitudes are an important input for misconduct (e.g., Becker [1962] and Allingham and Sandmo [1972]), surprisingly, few studies have identified risk preferences as an individual determinate of misconduct. Other stable individual traits have been found to be important predictors of deviant behavior, including the "dark triad" personality traits: Machiavellianism , Narcissism , and Psychopathy ((Hegarty and Sims [1978], Jones and Kavanagh [1996], Moore et al. [2012], and O'Boyle et al. [2012]). Two of the "Big 5" personality traits have also found to be predictors of behavior (and of workplace performance): agreeableness and conscientiousness (Salgado [2002] and Mount et al. [2006]). Other predictors include social value orientation, trait anger and negative affectivity, self-control and locus of control (Hegarty and Sims [1978], Douglas and Martinko [2001], and Brizi et al. [2015]). Thus, we add to this literature by documenting risk preferences as an important individual trait leading to increased misconduct.

In sum, we see our paper as providing four contributions. First, we document risk preferences as a meaningful antecedent for misconduct. Second, we find that for the important setting of politicians, increased risk appetite predicts increased misconduct. Third, we validate portfolio choices as a valuable way to identify risk preferences in the field. Fourth, we show that standard low-stakes elicitations can 
accurately predict high-stakes choices many order of magnitudes larger than smallstakes elicitations (i.e., over 10,000 to 1 ).

\section{Risk-taking and Misconduct}

US politicians provide an attractive setting for testing the notion of portfolio allocation as a means of identifying individual risk for several reasons. First, and foremost, US politicians are required to disclose financial transactions, including the nature of their asset and investment holdings, enabling us to construct portfolio allocation choices. Second, politicians provide an observable, high-stakes outcome variable that is tied to risk-taking: misconduct. Political misconduct may provide a private benefit to politicians (often financial, sometimes personal), though it often leads to well-publicized scandals and high-stakes consequences if discovered, including financial costs, destroyed fraternal and familial relations, damaged careers and incarceration. Third, a better understanding of risk-taking politicians who get involved in scandals could be an important finding in its own right.

\section{$1.1 \quad$ Data}

We received data from OpenSecrets.org, who were able to obtain data on US politicians' financial transactions from 2004 through 2009. They hand collected and digitized all reports for this period. Included in financial transactions are all portfolio holdings, including real estate, retirement accounts and taxable investment accounts, as well as the debt obligations of politicians. See Eggers and Hainmueller (2013) who use this data to study politician insider-trading.

Converting asset holdings into portfolio allocations requires several steps. First, some holdings are direct holdings: a politician holds direct shares of company stock or bonds. Thus, these holdings are relatively straight forward to categorize as stock and bond investments. Second, many holdings are classified as mutual funds. There are over 10,000 possible mutual funds among which one can choose. We use keywords 
found in fund names to classify these funds as stock or bond. ${ }^{3}$ The final result, as shown in the summary statistics Table 1, suggests that the average politician has an investment portfolio of approximately $\$ 4.5$ million and investment allocation to stocks of $57 \%$. This allocation is similar to a $60 \%$ stock allocation suggested as a "typical" balanced portfolio by investment professionals. Figure 1 shows the distribution of allocations, conditional on having at least $\$ 1$ of investments. Approximately $27 \%$ of politicians invest $100 \%$ of their portfolio in stocks, or riskier investments. Hence, based on our discussion in Section (2), we cannot rule out that some politicians are risk-seekers. There are also roughly $17 \%$ that invest $100 \%$ of their funds in bonds, or safer investments. And the balance, or the majority of politicians, choose an interior allocation. We also aggregated the total value of all asset and debt holdings to calculate total financial leverage, as well as overall wealth.

We hand collected biographical data on all politicians in the sample. We identified whether they obtained an MBA or JD degree, the length of any military service, their date of birth, marital status, number and gender of children, political identity (i.e., Republican, Democrat, or Independent), which congressional chamber they served in, and their tenure in congress. This data is generally self-disclosed on politicians' websites.

To control for political ideology, which could also influence propensity for misconduct, we obtained DW Nominate scores (see Poole \& Rosenthal [1996] for a full explanation). These scores measure a particular politician's ideology as given by her voting history. There are two dimensions: DW Nominate 1 and DW Nominate 2. DW Nominate 1 measures the degree of support for government intervention legislation and DW Nominate 2 measures degree of support for civil rights legislation. In the data, these two dimensions have a correlation of only -.03. Thus, it seems that they measure two orthogonal dimensions of political ideology.

\footnotetext{
${ }^{3}$ Our mutual fund classification algorithm was based on discussions with industry insiders. In particular funds with the following words in their name were classified as stock: 100, 400, 500, 600, 1000, 2000, 3000, aggressive, bank, blue chip, concentrated, currencies, currency, developing, emerging, energy, equity, financial, focus, global, gold, growth, health, international, intl, large, medium, metals, mid, msci, natural resource, precious metal, real estate, science, sector, sectors, small, stock, tech, technology, windsor, world, and value.
} 
For identifying political scandals, we obtained data from the organization Citizens for Responsibility and Ethics in Washington (hereafter, CREW). Since 2005, CREW has created an annual report titled "CREW's Most Corrupt." CREW reports their research methodology thus:

"To create this report, CREW reviewed media articles, OCE and House Ethics Committee reports, Federal Election Commission reports, court documents, and members' personal financial and travel disclosure forms. We then analyzed that information in light of federal laws and regulations, as well as congressional ethics rules."4

This report details scandals of politicians, including the nature of the scandal and the year in which the alleged misconduct took place. For our analysis, we use the year of alleged misconduct rather than the date of discovery or indictment because sometimes a politician resigns in order to avoid further investigation and prosecution.

A recent example from Illinois state that illustrates the nature of the CREW data comes from Jesse Jackson Jr., the former US House of Representative from the 2nd District of Illinois. CREW's data identifies his alleged misuse of his campaign funds in 2009. He purportedly used an estimated $\$ 750,000$ of these funds for 3,000 personal purchases. In October 2012, it was publicly disclosed that the FBI and federal prosecutors began investigating these improprieties. Nonetheless, Jackson was reelected in November 2012. In February 2013, the Justice Department filed charges, to which Jackson pled guilty. He started serving his 30-month prison sentence October of 2013, though this event is reported in the CREW data as a campaign finance scandal occurring in 2009, the year of discovery. My empirical analysis contains events that occurred between 2005 and 2010. Hence, as long as any misconduct happening between 2005 through 2010 was discovered by 2014, it is included in the data as the year in which the alleged misconduct occurred.

\footnotetext{
${ }^{4}$ Further information is available here: http://www.crewsmostcorrupt.org/mostcorrupt/entry/aboutthe-report.
} 


\subsection{Results}

Before engaging in regression analysis, we simply consider the asset allocation of politicians that were involved in at least one scandal versus those that were scandalfree from 2005 through 2010. The chart below reports that those involved in at least one scandal hold an average of $64 \%$ stocks compared to those with no scandal who hold an average of $54 \%$ stocks. A t-test reveals that this difference is significant at the $1 \%$ level.

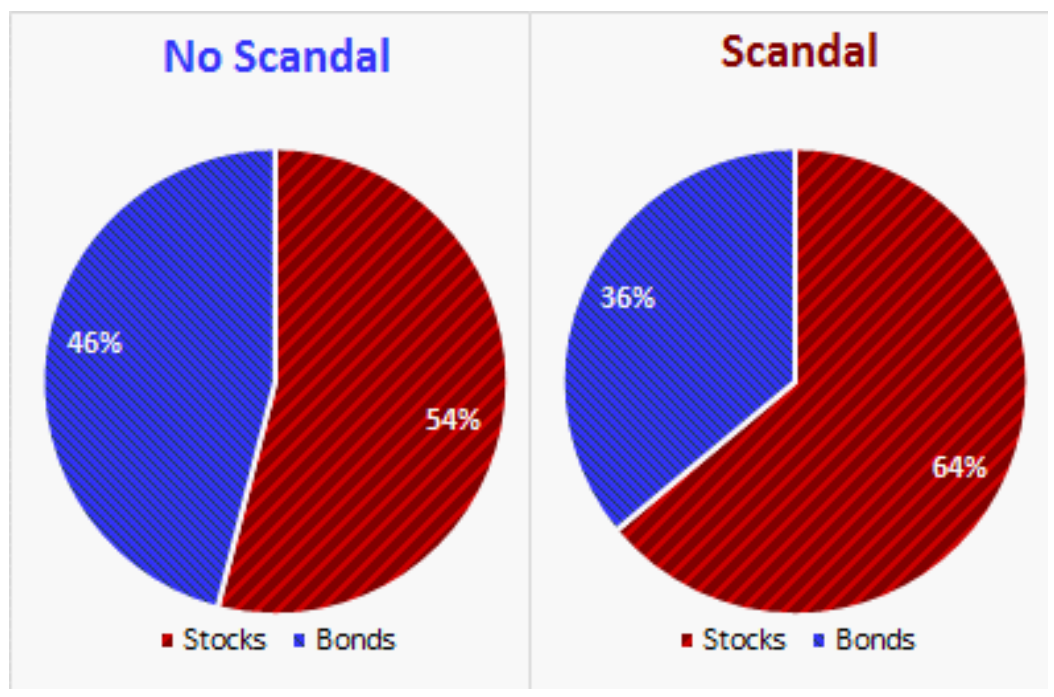

Another simple way to view the data is to split the sample into politicians with over 50\% risky assets (i.e., stocks) and those with less than 50\% stocks. Here, we find that $28 \%$ more politicians have more than $50 \%$ of their money in stocks and that these same politicians are over $100 \%$ more likely to be involved in at least one scandal. The table below reports these numbers, which are also significantly different at the $1 \%$ level, as calculated by a t-test: 


\begin{tabular}{|c|c|c|}
\hline $\begin{array}{c}\text { Average } \\
\text { Allocation }\end{array}$ & $\begin{array}{c}\text { Total } \\
\text { Politicians }\end{array}$ & $\begin{array}{c}\text { Politicians with } \\
\text { Scandals }\end{array}$ \\
\hline $\begin{array}{c}\text { More than } \\
50 \% \text { in Stocks }\end{array}$ & 357 & 121 \\
\hline $\begin{array}{c}\text { Less than } \\
50 \% \text { in Stocks }\end{array}$ & 278 & 59 \\
\hline
\end{tabular}

Here, we are not controlling for potentially important factors that might influence both politicians' portfolio choices and propensity for misconduct. To explore this further, we now turn to regression analysis. Table 2 reports the results of a linear panel model with random effects. We test the use of random effects over fixed effects in the linear panel model. Since there is potentially serial correlation within politicians, a variation of the Houseman test should be used (See Wooldridge [2002]). Using this test, we find that the Sargan-Hansen statistic yields a $\chi^{2}$ value of 14.333, which generates a $p$ value of 0.3508 . This means that if a linear fixed effect model is appropriate, the linear random effects model is the more appropriate model to use, as it is more efficient.

The coefficient estimate on portfolio stock allocation for the previous year, with all controls (i.e., see column (5)), is .03. With a baseline annual scandal rate of .04, this estimate suggests that a politician with $100 \%$ stocks compared to a politician with $100 \%$ bonds has a $75 \%$ greater probability of being involved in a scandal.

We expect risk preferences to be a relatively stable individual characteristic. Thus, a fixed effect panel model should eliminate the relationship of the portfolio stock allocation and misconduct, as the individual fixed effect will absorb the individual risk preference that determines the allocation, whereas a random effects model allows invariant coefficients to be estimated. Although even without this theory the random effects model is the more appropriate model for estimating coefficients (as shown above), to test our conjecture we run the same analysis that generates column 
(5) in Table 2 with fixed effects rather than random effects, and as expected, the coefficient estimate becomes statistically no different from zero (-.0209 with p-value $.504)$.

Since we are studying binary outcomes, we should also consider a model other than the linear probability model, since the latter does not explicitly account for the fact that the outcome must be either zero or one. Thus, we recreate the analysis of Table 2 using a logit panel model. The results are reported in Table 3. The coefficient estimate on portfolio stock allocation for the previous year is roughly .75, with all controls (column 5). In terms of odds, this means that a politician with $100 \%$ stock has over double the odds of becoming involved in a scandal the next year than a politician with $100 \%$ bonds. $^{5}$

Motivated by our measure of risk preferences seeming stable over time, we conduct our analysis henceforth by collapsing the panel to a cross section and focusing on the logit model results; linear and Probit models provide very similar results. Table 4 reports these cross section results. With all controls (column 5), the previous stock allocation coefficient estimate is .71 versus .75 when using a panel model. Thus, as expected if risk preferences, as measured by portfolio allocation, are relatively stable over time, we obtain very little new information in the panel compared to the cross section.

As mentioned in the introduction, there has been debate over whether or not risk preferences are domain dependent. To explore this possibility we partition our events into financial and non-financial events. A financial event is defined as a scandal where the politician has financially enriched herself or her family through the improper obtaining or disbursing of funds. The residual scandals are coded as non-financial, and can include anything from treating staff poorly to participating in a sexual affair or engaging in on-the-job drunkenness. This generates a mix of roughly $28 \%$ nonfinancial and $72 \%$ financial related scandals. Table 5 reports column (5) from Table 4 in column (1). Columns (2) and (3) are the results of the same analysis as column (1) in Table 5, but here we use only financial and non-financial linked scandals,

\footnotetext{
${ }^{5}$ Recall that to convert the logit coefficient estimate to an odds ratio, $e$ is raised to the power of the coefficient value. Here, this means the odds ratio is approximately $e^{.75}=2.117$.
} 
respectively. While the coefficient estimate on portfolio stock allocation for financial linked scandals is still significant, the coefficient on stock allocation for non-financial scandals is no longer significant. However, although attenuated, the latter coefficient is still positive. This is likely the result of fewer scandal outcomes when dividing scandals between financial and non-financial, and may also be due to the fact that non-financial scandals cover a greater range of domains than financial, as mentioned above. Nevertheless, the finding does suggest some caution in assuming that risk preferences globally span all domains of risk-taking.

Whatever the case, although portfolio choice strongly predicts scandals, a question that cannot be addressed thus far is whether or not one's portfolio allocation choice is capturing individual risk preferences or something else. To address this issue we first turn to theoretically showing that a portfolio allocation choice between a risky and safe investment is isomorphic to a choice from a multiple price list lottery. Next, we conduct a field experiment amongst wealthy investors to further validate portfolio choice as an indication of individual risk preferences.

\section{Theoretical Considerations}

We present some simple theoretical considerations to link the choices in a multiple price lottery to that of a portfolio choice. Holt and Laury (2002), hereafter HL, use the following utility function to identify risk preferences:

$$
U(x)=\left\{\begin{array}{ll}
\frac{x^{1-r}}{1-r} & \text { if } r \neq 1 \\
\log x & \text { if } r=1
\end{array} .\right.
$$

To formalize HL's approach, we fix the payoffs of two lotteries, which we denote as sets of possible outcomes for lotteries $A$ and $B$. Specifically, $A=\left\{a_{1}, a_{2}\right\}$ and $B=\left\{b_{1}, b_{2}\right\}$, where payoffs are ordered as $0<b_{1}<a_{1}<a_{2}<b_{2}$. The payoff $a_{1}$ and $b_{1}$ occur at the same probability $1-p$ and $a_{2}$ and $b_{2}$ both occur at probability $p$. HL then vary $p$ by increments of $10 \%$ across choices to determine when a subject prefers set $A$ versus $B$. If subjects could instead choose from a continuous set of $p^{\prime} s$, there is theoretically some $p^{*}$ such that $A \sim B$. For all $p<p^{*}, A \succ B$ and for all $p>p^{*}$, 
$B \succ A$. From this, we can precisely identify the risk parameter $r$ by solving

$$
p^{*} \frac{\left(a_{2}\right)^{1-r}}{1-r}+\left(1-p^{*}\right) \frac{\left(a_{1}\right)^{1-r}}{1-r}=p^{*} \frac{\left(b_{2}\right)^{1-r}}{1-r}+\left(1-p^{*}\right) \frac{\left(b_{1}\right)^{1-r}}{1-r} .
$$

When instead, as is common practice, subjects choose from a finite set of probabilities, $r$ can only be identified within some interval.

Now, consider an investor choosing her portfolio and assume that she must allocate between a risky and safe investment. She must then solve the following program to find her optimal allocation $\alpha^{*}$ to her risky investment (and $1-\alpha^{*}$ to her safe investment).

$$
\max _{\alpha} \int_{-\infty}^{+\infty} U(x(t)) f(t) d t,
$$

where the risky investment has total return ${ }^{6} R(t)$ and the safe investment total return $S, f(t)$ is the density of the distribution of returns, $x(t):=W[\alpha R(t)+(1-\alpha) S]$, $W$ is the investor's beginning portfolio value, and $U$ is defined by equation (1). We assume that $E[R(t)]>S$, which means the expected return of the risky investment is greater than the safe investment. If this is not true, all risk averse (and risk-neutral) investors will invest solely in the safe investment (i.e., $\alpha^{*}=0$ ).

Solving for our first order condition yields

$$
\begin{aligned}
& \frac{d}{d \alpha} \int_{-\infty}^{+\infty} U(x(t)) f(t) d t \\
= & \int_{-\infty}^{+\infty} \frac{d}{d \alpha} U(x(t)) f(t) d t
\end{aligned}
$$

\footnotetext{
${ }^{6}$ Here total return means the percentage return of the invesment added to $100 \%$. For example, if a return of the risky investment is $10 \%$, its total return is $110 \%$.
} 


$$
=\int_{-\infty}^{+\infty} \frac{W(R(t)-S)}{(W[\alpha(R(t)-S)+S])^{r}} f(t) d t:=0 .
$$

Our second order condition is

$$
\begin{aligned}
& \frac{d}{d \alpha} \int_{-\infty}^{+\infty} \frac{W(R(t)-S)}{(W[\alpha(R(t)-S)+S])^{r}} f(t) d t \\
= & \int_{-\infty}^{+\infty} \frac{-r W(R(t)-S)^{2}}{(W[\alpha(R(t)-S)+S])^{r+1}} f(t) d t<>0
\end{aligned}
$$

The second order condition is strictly negative with $r>0$ (i.e., risk aversion) and strictly positive with $r<0$ (i.e., risk seeking). Now note when $\alpha=0$, the first order condition from (3) becomes

$$
\begin{gathered}
\int_{-\infty}^{+\infty} \frac{W(R(t)-S)}{(W S)^{r}} f(t) d t \\
=\frac{W}{(W S)^{r}} \int_{-\infty}^{+\infty}(R(t)-S) f(t) d t>0 .
\end{gathered}
$$

The final inequality follows from $E[R(t)]>S$. Equation (5) means that risk seeking (and risk neutral) investors will allocate all funds to the risky investment by choosing $\alpha^{*}=1$. Risk averse investors, however, will choose some $\alpha^{*} \in[0,1]$, depending on their degree of risk aversion. Note that this exposes a weakness of using the allocation choice of risky and safe investments to identify individual risk preferences: the degree of risk preferences will be identified only for some risk averse subjects. That is, for the set of risk averse investors that choose $\alpha^{*}=1$ we cannot identify their $r$ but instead can only bound it from above, along with all of the other subjects that are risk neutral or risk-seeking. Nevertheless, all investors, regardless 
of risk type, will choose some unique $\alpha^{*} \in[0,1] .^{7} \mathrm{~A}$ unique $\alpha^{*}$ assures that we can identify any investor's risk preferences: either via an upper bound of $r$ or a specific value of $r$ when $\alpha^{*}$ is interior.

Also note that the first order condition (3) is strictly decreasing in the degree of risk aversion $r$. This, along with the second order condition (4), tells us that per the implicit function theorem, risk averse investors' allocation choice $\alpha^{*}$ is strictly decreasing in the degree of risk aversion $r$. This means, as expected, more risk averse investors allocate less to the risky investment. We now collect three primary results from the above analysis, linking HL-type lottery choices and portfolio choices:

1. Regardless of risk preferences, subjects choose a unique allocation $\alpha^{*} \in[0,1]$

2. The allocation choice $\alpha^{*}$ identifies risk preference $r$ up to an interval and uniquely when $\alpha^{*}$ is interior

3. Allocation choice $\alpha^{*}$ is strictly decreasing in risk aversion $r>0$

\section{Risk Elicitation Field Experiment}

Motivated by the above theory, we conduct a field experiment to empirically validate the relationship of investment allocation to general risk preference. Specifically, in the style of HL, we elicit low-stakes lottery choices, and then relate these to actual portfolio allocation choices and overall portfolio risk.

\subsection{Methodology}

Wealthy investors are an ideal subject pool to explore the relationship between real investment choices and conventional experimental measures of risk. Studying this group of individuals provides the opportunity to test both high- and low-stakes risk preferences. In addition, these investors are more likely to have heterogeneous risk

\footnotetext{
${ }^{7} \mathrm{An}$ investor chooses to invest only in the safe investment (i.e., $\alpha^{*}=0$ ) with maximal risk aversion (i.e., as $r \rightarrow+\infty$ ).
} 
preferences (which aids in identification), in contrast to institutional or corporate investors, which are often considered risk-neutral.

Motivated by these features of individual wealthy investors, we engaged with an investment management firm (hereafter "Firm") to offer real lottery choices to its clients. In particular, we were able to send a voluntary incentivized survey to their 154 clients that consisted of an HL-style set of lottery choices. The Firm made it clear that this survey was voluntary and that a client's answers would have no bearing on their portfolios. The Appendix includes the form they were sent. The Firm paid the clients in dinner gift certificates, as regulations prevent direct cash payments to clients. The Firm randomly chose the row to pay all clients from, which resulted in row 1 (i.e., $10 \%$ chance of $\$ 60$ and $90 \%$ chance of $\$ 50$ for Option A). Next, the Firm chose the payoff for each client based on their choice. All clients chose A for row one, which resulted in each client facing a payoff of $\$ 60$ with probability $10 \%$ and $\$ 50$ which probability $10 \%$. The firm received 101 survey responses from investors and payments averaged $\$ 50.90$.

In addition to the survey responses, the firm also provide us with the investors' actual portfolio allocation choices made prior to taking the survey, a client's expected portfolio risk (as measured by the standard deviation of portfolio returns), and a client's response to the following question:

Choose which of the following three portfolios you would most prefer to invest in (check one):

( ) Most years (70\%) your portfolio value goes up by $9.5 \%$ on average and the rest of the years $(30 \%)$ your portfolio value goes down by $2 \%$ on average

( ) Most years (70\%) your portfolio value goes up by $12 \%$ on average and the rest of the years (30\%) your portfolio value goes down by $5.5 \%$ on average

( ) Most years (70\%) your portfolio value goes up by $14.5 \%$ on average and the rest of the years (30\%) your portfolio value goes down by $9 \%$ on average

The Firm described a client's choice above as reflecting their preference towards their portfolio's risk-taking. In particular, the question above is based on historical outcomes of a portfolio that allocates $40 \%, 60 \%$, and $80 \%$ to a risky versus safe investment (i.e., US stocks versus US bonds). These allocations were suggested 
by the Firm as a range of "typical" allocations. As assumed in Section (2), the risky investment also has a higher return than the safe investment empirically (i.e., $\left.p R_{g}+(1-p) R_{l}>S\right)$. Nonetheless, although a client's choice of one of the above three options generates a "suggested" allocation to them, the client decides their ultimate portfolio allocation.

\section{$3.2 \quad$ Results}

Table 6 reports the summary statistics for the data discussed above. The variable "Choose B" records when the subject's lottery choice switched from lottery A to lottery B for the low-stakes lotteries. There was no instance of a subject switching back to A after choosing B. There was also no instance of a subject choosing A for the final choice; such a choice would not be rational since B is guaranteed to provide a higher payoff then A for any type of risk preferences. Finally, there was only one instance of a subject choosing a lottery that indicates they are not risk-averse - the choice 40 represents switching to Option B when the probability of the higher payoff is $40 \%$. All other 100 investors chose B at 50 or higher, which means that they are all risk-averse. This $1 \%$ of subjects who are not being risk-averse is in contrast to HL, where for their "high-stakes" 20X treatment (which is comparable in stakes to our lottery setting) they find that $19 \%$ are not risk-averse. The mean of Choose B is approximately 73 , which implies that, on average, subjects switch once there is over a $70 \%$ chance of the higher payoff. For our study, $18 \%$ of subjects switched before a $70 \%$ chance of a higher payoff. This is compared to $60 \%$ of subjects switching before $70 \%$ in HL for the 20X real stakes treatment. Figure 2 reports the histogram of Choose B lottery choices for all 101 subjects.

Also reported in Table 6 is Downside Percent, which is coded as 2, 5.5, or 9 depending on if they choose the 1st, 2nd, or 3rd option from above. Here, the larger the number, the less risk averse an investor should be. Allocation represents a client's actual allocation choice between stocks and bonds in their portfolio. Allocations vary from $7 \%$ to $100 \%$ stocks, with a mean of $45 \%$. Portfolio Risk is the expected standard deviation of a client's annual portfolio returns. 
We want to ask if an investor's choice in a low-stakes HL-type lottery predicts investors high-stakes portfolio allocation choices. The following chart explores this question by plotting an investor's actual portfolio choice as a function of when he switches from Option A to Option B. Specifically, we plot in Choose B bins the average allocation of stocks in a portfolio:

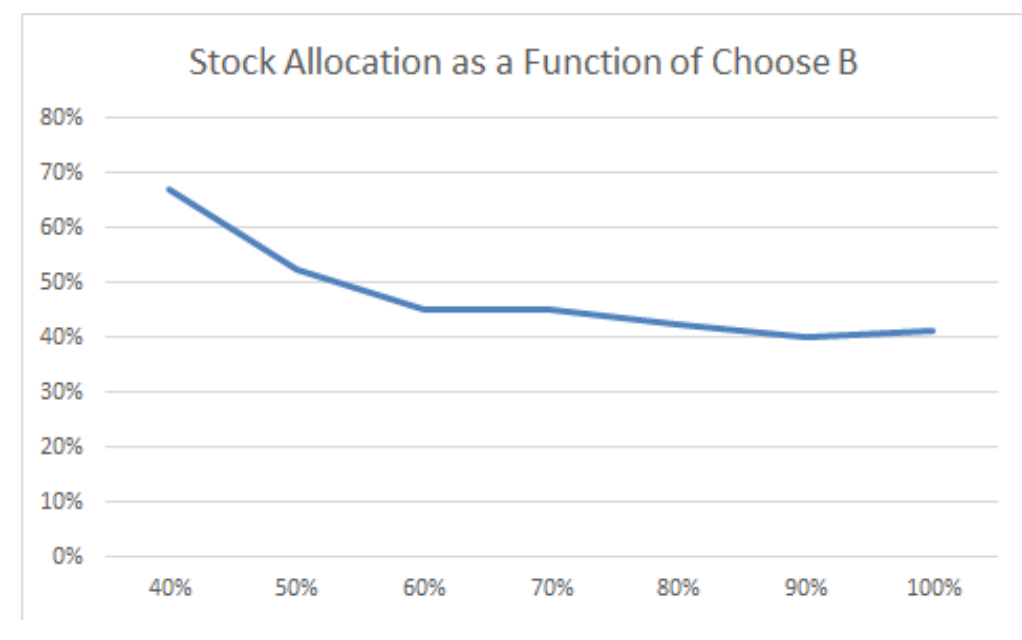

The chart is negatively sloping, indicating that investors who make more riskaverse choices in the small-stakes HL lottery also make more risk-averse choices in their high-stakes real portfolio choices.

Now we correlate both the Choose B and Downside Percent with two of the measures of high-stakes risk-taking - the investor's actual Portfolio Allocation and Portfolio Risk (i.e., the expected standard deviation of portfolio returns). Table 7 reports the results of regression analysis of these correlations. Both the low-stakes investor choice (i.e., Choose B) and high-stakes choice (i.e., Downside Percent) are strong predictors of high-stakes risk-taking; all coefficients are significant at the $1 \%$ level. In terms of magnitude, a one standard deviation increase in Choose B results in $24 \%$ (23\%) of one standard deviation increase in Portfolio Allocation (Portfolio Risk). The high-stakes choice predicts in a very similar magnitude: a one standard deviation increase in Downside Percent results in 27\% (26\%) of one standard deviation increase in Portfolio Allocation (Portfolio Risk). Overall, this suggests that while we know the absolute level of risk aversion can be quite different across varying levels 
of stakes, here we find an average $\$ 51$ and $\$ 700,000$ stakes choice to similarly predict actual high-stakes risk-taking. This suggests that the relative choices in small-stakes lotteries can still predict relative choices in large-stakes settings. More importantly for this paper, these findings also suggest that measuring actual portfolio choices between stocks and bonds is identifying an underlying risk preference as we understand it in the extant literature.

\section{Conclusion}

We found risk preferences to be an important antecedent of misconduct. Risk preferences were measured by portfolio choices between risky and safe investments and found to strongly predict political scandals. We validated portfolio choice as a measure of latent risk preferences through administering low-stakes multi price list style (MPL) lotteries to wealthy investors and correlating their lottery choices to actual portfolio choices. We found the relative lottery choices to be robust predictors of relative high-stakes risk-taking. In sum, this suggests that MPL lotteries ubiquitous in laboratory work are actually very useful in predicting high-stakes outcomes in the field. It also suggests that portfolio choices can be used as an alternative way to capture risk preferences when laboratory results are not obtainable.

More broadly our results also suggest a tradeoff in choosing risk-taking leaders. Voters might seek a politician with a capacity for making significant policy changes, which often requires risk-taking. However, such a politician is more prone to misuse funds and engage in other forms misconduct. Similarly, our results suggest that those managers and entrepreneurs called upon to engage in risk-taking are also more likely to take advantage of their organization and other stakeholders. It seems that future theoretical and experimental research could better inform us of these and other tradeoffs when employing risk-taking leaders. We leave this to future research. 


\section{References}

[1] Ahn, T. (2010). Attitudes toward risk and self-employment of young workers. Labour Economics, 17(2), 434-442.

[2] Allingham, M. G., \& Sandmo, A. (1972). Income tax evasion: a theoretical analysis. Journal of Public Economics, 1(3-4), 323-338.

[3] Arrow, Kenneth J. "The theory of risk aversion." Essays in the theory of riskbearing (1971): 90-120.

[4] Bombardini, M., \& Trebbi, F. (2012). Risk aversion and expected utility theory: an experiment with large and small stakes. Journal of the European Economic Association, 10(6), 1348-1399.

[5] Brizi, A., Giacomantonio, M., Schumpe, B. M., \& Mannetti, L. (2015). Intention to pay taxes or to avoid them: The impact of social value orientation. Journal of Economic Psychology, 50, 22-31.

[6] Charness, G., Gneezy, U., \& Imas, A. (2013). Experimental methods: Eliciting risk preferences. Journal of Economic Behavior \& Organization, 87, 43-51.

[7] Dohmen, T., Falk, A., Huffman, D., Sunde, U., 2011. Individual risk attitudes: measurement, determinants and behavioral consequences. Journal of the European Economic Association 9 (3), 522-550

[8] Douglas, S. C., \& Martinko, M. J. (2001). Exploring the role of individual differences in the prediction of workplace aggression. Journal of Applied Psychology, $86(4), 547$.

[9] Eggers, A., \& Hainmueller, J. (2013). Capitol losses: The mediocre performance of Congressional stock portfolios. The Journal of Politics, 75(02), 535-551.

[10] Fairlie, R. W. (2002). Drug Dealing and Legitimate Self-Employment. Journal of Labor Economics, 20(3), 538-537. 
[11] Gino, F., \& Ariely, D. (2012). The dark side of creativity: original thinkers can be more dishonest. Journal of personality and social psychology, 102(3), 445.

[12] Hathaway, I., \& Litan, R. E. (2014). Declining business dynamism in the United States: A look at states and metros. Brookings Institution.

[13] Hegarty, W. H., \& Sims, H. P. (1978). Some determinants of unethical decision behavior: An experiment. journal of Applied Psychology, 63(4), 451

[14] Holt, C. A., \& Laury, S. K. (2002). Risk aversion and incentive effects. American economic review, 92(5), 1644-1655.

[15] Housman, M. \& Minor, D. (2015). Toxic Workers. Harvard Business School Working Paper 16-057.

[16] Hvide, H. K., \& Panos, G. A. (2014). Risk tolerance and entrepreneurship. Journal of Financial Economics, 111(1), 200-223.

[17] Jones, G. E., \& Kavanagh, M. J. (1996). An experimental examination of the effects of individual and situational factors on unethical behavioral intentions in the workplace. Journal of Business Ethics, 15(5), 511-523.

[18] Kogan, N., \& Wallach, M. A. (1964). Risk taking: A study in cognition and personality.

[19] Koudstaal, M., Sloof, R., \& van Praag, M. (2015) Risk, Uncertainty, and Entrepreneurship: Evidence from a Lab-in-the-Field Experiment. Management Science

[20] MacCrimmon, K. R., \& Wehrung, D. A. (1990). Characteristics of risk taking executives. Management science, 36(4), 422-435.

[21] MacCrimmon, K. R., Wehrung, D., \& Stanbury, W. T. (1986). Taking risks. Simon and Schuster. 
[22] March, J. G., \& Shapira, Z. (1987). Managerial perspectives on risk and risk taking. Management science, 33(11), 1404-1418.

[23] Markowitz, H. (1952). Portfolio selection*. The journal of finance, 7(1), 77-91.

[24] Merton, R. C. (1969). Lifetime portfolio selection under uncertainty: The continuous-time case. The review of Economics and Statistics, 247-257.

[25] Moore, C., Detert, J. R., Klebe Treviño, L., Baker, V. L., \& Mayer, D. M. (2012). Why employees do bad things: Moral disengagement and unethical organizational behavior. Personnel Psychology, 65(1), 1-48.

[26] Mount, M., Ilies, R., \& Johnson, E. (2006). Relationship of personality traits and counterproductive work behaviors: The mediating effects of job satisfaction. Personnel psychology, 59(3), 591-622.

[27] O’Boyle Jr, E. H., Forsyth, D. R., Banks, G. C., \& McDaniel, M. A. (2012). A meta-analysis of the dark triad and work behavior: A social exchange perspective. Journal of Applied Psychology, 97(3), 557.

[28] Poole, K. T., \& Rosenthal, H. (1997). Congress: A political-economic history of roll call voting. Oxford University Press.

[29] Sahm, C. R. (2012). How much does risk tolerance change?. The quarterly journal of finance, 2(04), 1250020.

[30] Salgado, J. F. (2002). The Big Five personality dimensions and counterproductive behaviors. International Journal of Selection and Assessment, 10, 117-125.

[31] Samuelson, P. A. (1969). Lifetime portfolio selection by dynamic stochastic programming. The review of economics and statistics, 239-246

[32] Schumpeter, J. A. (1942). Capitalism, socialism and democracy. Routledge.

[33] Weber, E. U., \& Milliman, R. A. (1997). Perceived risk attitudes: Relating risk perception to risky choice. Management Science, 43(2), 123-144. 
[34] Weber, E. U., Blais, A. R., \& Betz, N. E. (2002). A domain-specific risk-attitude scale: Measuring risk perceptions and risk behaviors. Journal of behavioral decision making, 15, 263-290.

[35] Wooldridge, J.M. 2002. Econometric Analysis of Cross Section and Panel Data. Cambridge, MA: MIT Press. 


\section{Appendix}

The survey sent to clients by the Firm was presented as follows:

The questions on this page are optional and will not affect your account profile. If completed, the survey results will then be used to research improving overall risk management. These final questions represent an economic game for which we will be sending you a restaurant gift certificate. The value will be based on the outcome of your following answer choices. In particular, we will randomly choose (with equal chance) one of your choices to determine your final gift certificate value.

For each of the next ten choices, please check the option that you prefer for each row. Each option (i.e., A or B) represents what economists call a prospect. For example, if Option A for the first row is chosen, you will have a $10 \%$ chance of receiving a gift certificate valued at $\$ 60$ and a $90 \%$ chance of receiving a gift valued at $\$ 50$. If instead you choose Option $B$, you will have a $10 \%$ chance of receiving a $\$ 120$ gift certificate and a $90 \%$ chance of receiving a $\$ 5$ gift certificate.

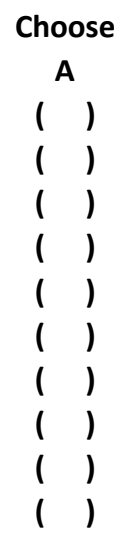

Option A

Chance Payment Chance Payment

\begin{tabular}{|l|ll|l|ll|}
\hline $10 \%$ & $\$$ & 60 & $90 \%$ & $\$$ & 50 \\
\hline $20 \%$ & $\$$ & 60 & $80 \%$ & $\$$ & 50 \\
\hline $30 \%$ & $\$$ & 60 & $70 \%$ & $\$$ & 50 \\
\hline $40 \%$ & $\$$ & 60 & $60 \%$ & $\$$ & 50 \\
\hline $50 \%$ & $\$$ & 60 & $50 \%$ & $\$$ & 50 \\
\hline $60 \%$ & $\$$ & 60 & $40 \%$ & $\$$ & 50 \\
\hline $70 \%$ & $\$$ & 60 & $30 \%$ & $\$$ & 50 \\
\hline $80 \%$ & $\$$ & 60 & $20 \%$ & $\$$ & 50 \\
\hline $90 \%$ & $\$$ & 60 & $10 \%$ & $\$$ & 50 \\
\hline $100 \%$ & $\$$ & 60 & $0 \%$ & $\$$ & 50 \\
\hline
\end{tabular}

Choose

B Chance Payment Chance Payment

OR
OR
OR
OR
OR
OR
OR
OR
OR
OR

$\begin{array}{ll}( & 1 \\ 1 & 1 \\ ( & 1 \\ 1 & 1 \\ 1 & 1 \\ 1 & 1 \\ ( & 1 \\ ( & 1 \\ 1 & 1 \\ ( & 1\end{array}$

\begin{tabular}{|c|cc|c|ll|}
\hline $10 \%$ & $\$$ & 120 & $90 \%$ & $\$$ & 5 \\
\hline $20 \%$ & $\$$ & 120 & $80 \%$ & $\$$ & 5 \\
\hline $30 \%$ & $\$$ & 120 & $70 \%$ & $\$$ & 5 \\
\hline $40 \%$ & $\$$ & 120 & $60 \%$ & $\$$ & 5 \\
\hline $50 \%$ & $\$$ & 120 & $50 \%$ & $\$$ & 5 \\
\hline $60 \%$ & $\$$ & 120 & $40 \%$ & $\$$ & 5 \\
\hline $70 \%$ & $\$$ & 120 & $30 \%$ & $\$$ & 5 \\
\hline $80 \%$ & $\$$ & 120 & $20 \%$ & $\$$ & 5 \\
\hline $90 \%$ & $\$$ & 120 & $10 \%$ & $\$$ & 5 \\
\hline $100 \%$ & $\$$ & 120 & $0 \%$ & $\$$ & 5 \\
\hline
\end{tabular}


Table 1: Summary Statistics for Politician Data

\begin{tabular}{|c|c|c|c|c|c|c|}
\hline Variable & Obs & Mean & & Std. Dev. & Min & Max \\
\hline Scandal $(1,0)$ & 2848 & 0.04 & & 0.19 & 0 & 1 \\
\hline Stock Allocation & 2848 & $57 \%$ & & $39 \%$ & 0 & $100 \%$ \\
\hline Total Investments & $2848 \$$ & $4,506,713$ & $\$$ & $23,600,000$ & $\$ 500$ & $\$ 406,000,000$ \\
\hline Total Assets & $2848 \$$ & $6,744,923$ & $\$$ & $27,700,000$ & $\$ 1,503$ & $\$ 406,000,000$ \\
\hline Leverage (debt/ assets) & 2848 & 0.28 & & 2.42 & 0 & 116.43 \\
\hline MBA Degree & 2848 & 0.06 & & 0.24 & 0 & 1 \\
\hline Law Degree & 2848 & 0.34 & & 0.48 & 0 & 1 \\
\hline Years of Military Service & 2848 & 1.25 & & 3.53 & 0 & 31 \\
\hline Age & 2848 & 58.03 & & 9.86 & 29 & 92 \\
\hline Married & 2848 & 0.83 & & 0.38 & 0 & 1 \\
\hline Divorced & 2848 & 0.12 & & 0.33 & 0 & 1 \\
\hline \# of Daughters & 2848 & 0.61 & & 0.95 & 0 & 6 \\
\hline \# of Sons & 2848 & 0.69 & & 1.00 & 0 & 5 \\
\hline DW Nominate 1 & 2565 & 0.11 & & 0.49 & -0.71 & 1.23 \\
\hline DW Nominate 2 & 2565 & 0.05 & & 0.40 & -1.25 & 1.33 \\
\hline Member of House & 2848 & 0.75 & & 0.43 & 0 & 1 \\
\hline Congressional Tenure (years) & 2848 & 14.32 & & 10.39 & 0 & 44 \\
\hline
\end{tabular}


Figure 1: Distribution of Portfolio Allocations

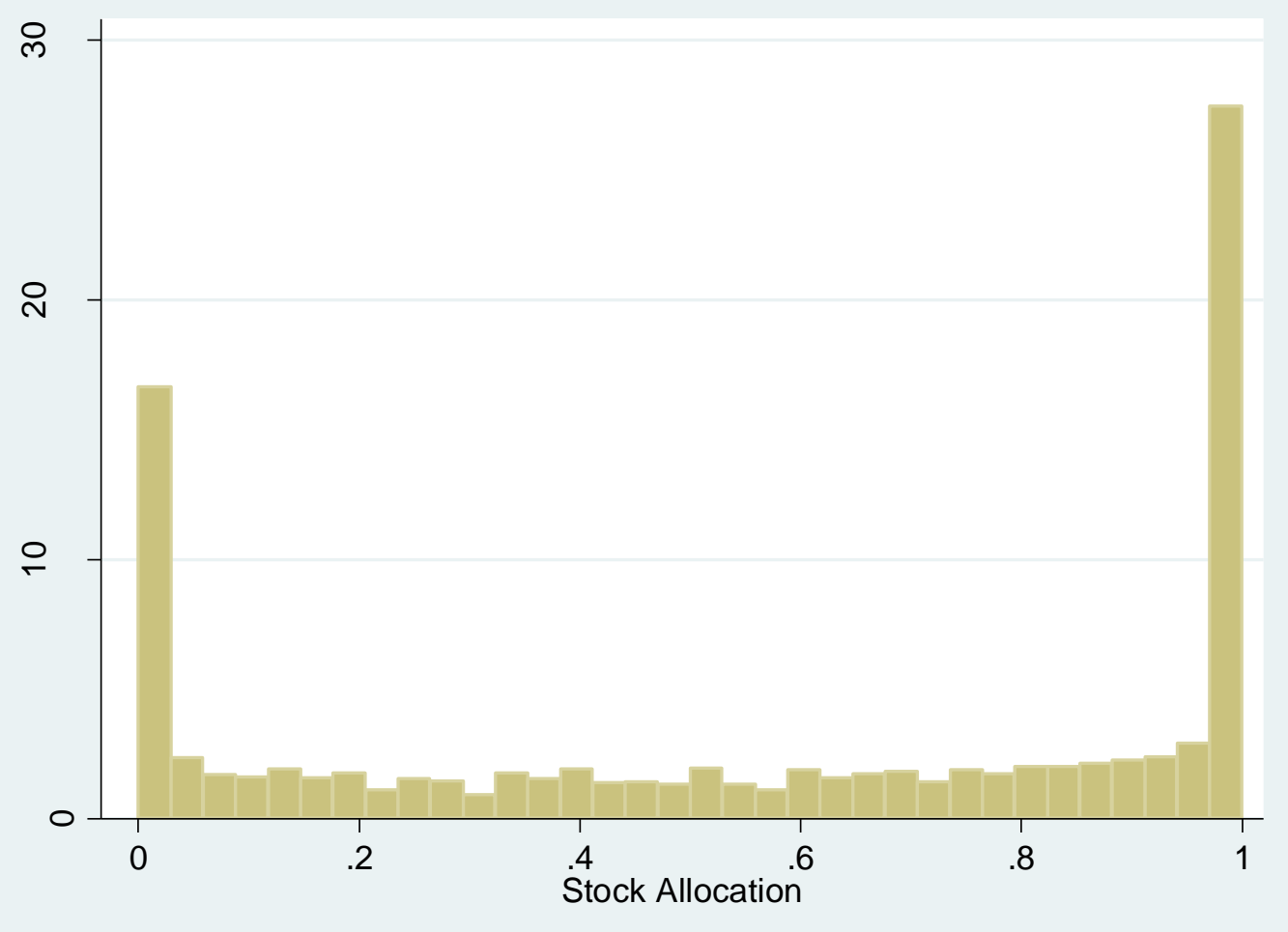


Table 2: Linear Panel Model of Politician Scandals

\begin{tabular}{|c|c|c|c|c|c|}
\hline \multicolumn{6}{|c|}{ Dependent Variable: Scandal $(1,0)$} \\
\hline & $(1)$ & $(2)$ & (3) & $(4)$ & $(5)$ \\
\hline Stock Allocation_t-1 & $\begin{array}{c}0.0307^{* *} \\
(2.38)\end{array}$ & $\begin{array}{c}0.0326 * * \\
(2.39)\end{array}$ & $\begin{array}{c}0.0316^{* *} \\
(2.21)\end{array}$ & $\begin{array}{c}0.0318^{* *} \\
(2.21)\end{array}$ & $\begin{array}{c}0.0303^{* * *} \\
(2.08)\end{array}$ \\
\hline DW Nominate 1 & & $\begin{array}{l}0.0200 \\
(1.64)\end{array}$ & $\begin{array}{c}0.0219 * \\
(1.80)\end{array}$ & $\begin{array}{c}0.0218^{*} \\
(1.78)\end{array}$ & $\begin{array}{c}0.0248 * \\
(1.95)\end{array}$ \\
\hline DW Nominate 2 & & $\begin{array}{l}-0.0096 \\
(-0.59)\end{array}$ & $\begin{array}{c}-0.0114 \\
(-0.69)\end{array}$ & $\begin{array}{c}-0.0115 \\
(-0.70)\end{array}$ & $\begin{array}{c}-0.0093 \\
(-0.55)\end{array}$ \\
\hline Member of House & & $\begin{array}{c}-0.0231 \\
(-1.34)\end{array}$ & $\begin{array}{c}-0.0241 \\
(-1.37)\end{array}$ & $\begin{array}{c}-0.0225 \\
(-1.27)\end{array}$ & $\begin{array}{c}-0.0192 \\
(-1.09)\end{array}$ \\
\hline Congressional Tenure & & $\begin{array}{l}0.0006 \\
(1.09)\end{array}$ & $\begin{array}{l}0.0007 \\
(1.19)\end{array}$ & $\begin{array}{l}0.0006 \\
(1.13)\end{array}$ & $\begin{array}{c}0.0004 \\
(0.58)\end{array}$ \\
\hline Random Politician Effects & Yes & Yes & Yes & Yes & Yes \\
\hline Year Fixed Effects & Yes & Yes & Yes & Yes & Yes \\
\hline Financial Controls & No & No & Yes & Yes & Yes \\
\hline Experience Controls & No & No & No & Yes & Yes \\
\hline Family Controls & No & No & No & No & Yes \\
\hline $\mathrm{N}$ & 2276 & 2126 & 2126 & 2126 & 2126 \\
\hline
\end{tabular}

Standard errors clustered at the politician level are used to report t statistics in parentheses

$* p<.10 * * p<.05 * * * p<.01$ 
Table 3: Logit Panel Model of Politician Scandals

\begin{tabular}{|c|c|c|c|c|c|}
\hline \multicolumn{6}{|c|}{ Dependent Variable: Scandal $(1,0)$} \\
\hline & (1) & (2) & (3) & (4) & (5) \\
\hline Stock Allocation_t-1 & $\begin{array}{c}0.7501^{* * *} \\
(2.86)\end{array}$ & $\begin{array}{c}0.8045^{* * *} \\
(2.85)\end{array}$ & $\begin{array}{c}0.7759 * * * \\
(2.70)\end{array}$ & $\begin{array}{c}0.7797^{* * *} \\
(2.70)\end{array}$ & $\begin{array}{c}0.7510^{* * *} \\
(2.59)\end{array}$ \\
\hline DW Nominate 1 & & $\begin{array}{l}0.3374 \\
(1.61)\end{array}$ & $\begin{array}{c}0.3876^{*} \\
(1.82)\end{array}$ & $\begin{array}{c}0.3832^{*} \\
(1.80)\end{array}$ & $\begin{array}{c}0.4556 * * \\
(2.05)\end{array}$ \\
\hline DW Nominate 2 & & $\begin{array}{c}-0.1322 \\
(-0.51)\end{array}$ & $\begin{array}{c}-0.1879 \\
(-0.71)\end{array}$ & $\begin{array}{c}-0.1898 \\
(-0.72)\end{array}$ & $\begin{array}{l}-0.1496 \\
(-0.56)\end{array}$ \\
\hline Member of House & & $\begin{array}{c}-0.4591^{*} \\
(-1.95)\end{array}$ & $\begin{array}{c}-0.4875^{* *} \\
(-2.03)\end{array}$ & $\begin{array}{c}-0.4576^{*} \\
(-1.88)\end{array}$ & $\begin{array}{c}-0.3868 \\
(-1.55)\end{array}$ \\
\hline Congressional Tenure & & $\begin{array}{l}0.0113 \\
(1.16)\end{array}$ & $\begin{array}{l}0.0131 \\
(1.33)\end{array}$ & $\begin{array}{l}0.0123 \\
(1.24)\end{array}$ & $\begin{array}{l}0.0078 \\
(0.66)\end{array}$ \\
\hline Random Politician Effects & Yes & Yes & Yes & Yes & Yes \\
\hline Year Fixed Effects & Yes & Yes & Yes & Yes & Yes \\
\hline Financial Controls & No & No & Yes & Yes & Yes \\
\hline Experience Controls & No & No & No & Yes & Yes \\
\hline Family Controls & No & No & No & No & Yes \\
\hline $\mathrm{N}$ & 2276 & 2126 & 2126 & 2126 & 2126 \\
\hline
\end{tabular}

t statistics reported in parentheses

$* p<.10 * * p<.05 * * * p<.01$ 
Table 4: Cross Section Logit Analysis of Scandals

\begin{tabular}{|c|c|c|c|c|c|}
\hline & Dependent & ariable: Any & Scandal $(1,0)$ & & \\
\hline Mean of Each Variable & (1) & $(2)$ & (3) & (4) & (5) \\
\hline Stock Allocation & $\begin{array}{c}0.9259^{* * *} \\
(3.48)\end{array}$ & $\begin{array}{c}0.8132^{* * *} \\
(2.86)\end{array}$ & $\begin{array}{c}0.7458^{* *} \\
(2.53)\end{array}$ & $\begin{array}{c}0.7170^{* *} \\
(2.42)\end{array}$ & $\begin{array}{c}0.7104^{* *} \\
(2.36)\end{array}$ \\
\hline DW Nominate 1 & & $\begin{array}{c}0.4180^{* *} \\
(2.01)\end{array}$ & $\begin{array}{c}0.6322^{* * *} \\
(2.96)\end{array}$ & $\begin{array}{c}0.6112^{* * *} \\
(2.86)\end{array}$ & $\begin{array}{c}0.6559 * * * \\
(2.97)\end{array}$ \\
\hline DW Nominate 2 & & $\begin{array}{l}0.0633 \\
(0.28)\end{array}$ & $\begin{array}{l}0.0108 \\
(0.04)\end{array}$ & $\begin{array}{l}-0.0025 \\
(-0.01)\end{array}$ & $\begin{array}{l}0.0137 \\
(0.05)\end{array}$ \\
\hline Member of House & & $\begin{array}{c}-0.4981^{* *} \\
(-2.20)\end{array}$ & $\begin{array}{c}-0.6146 * * * \\
(-2.64)\end{array}$ & $\begin{array}{c}-0.6046^{* *} \\
(-2.57)\end{array}$ & $\begin{array}{c}-0.5626^{* *} \\
(-2.33)\end{array}$ \\
\hline Congressional Tenure & & $\begin{array}{c}0.0232^{* * *} \\
(2.59)\end{array}$ & $\begin{array}{c}0.0264^{* * *} \\
(2.82)\end{array}$ & $\begin{array}{c}0.0262^{* * *} \\
(2.80)\end{array}$ & $\begin{array}{c}0.0254^{* *} \\
(2.33)\end{array}$ \\
\hline Log Total Investments & & & $\begin{array}{c}-0.1658 * * * \\
(-4.51)\end{array}$ & $\begin{array}{c}-0.1651^{* * *} \\
(-4.50)\end{array}$ & $\begin{array}{c}-0.1691^{* * *} \\
(-4.63)\end{array}$ \\
\hline Log Total Assets & & & $\begin{array}{l}0.0948 \\
(1.24)\end{array}$ & $\begin{array}{l}0.0929 \\
(1.21)\end{array}$ & $\begin{array}{l}0.0995 \\
(1.27)\end{array}$ \\
\hline Leverage & & & $\begin{array}{c}-0.0739 \\
(-1.38)\end{array}$ & $\begin{array}{c}-0.0706 \\
(-1.32)\end{array}$ & $\begin{array}{c}-0.0720 \\
(-1.39)\end{array}$ \\
\hline Log Total Debt & & & $\begin{array}{l}0.0242 \\
(1.29)\end{array}$ & $\begin{array}{l}0.0240 \\
(1.27)\end{array}$ & $\begin{array}{l}0.0246 \\
(1.28)\end{array}$ \\
\hline MBA Degree & & & & $\begin{array}{l}0.1734 \\
(0.43)\end{array}$ & $\begin{array}{l}0.1445 \\
(0.34)\end{array}$ \\
\hline Law Degree & & & & $\begin{array}{c}-0.0396 \\
(-0.19)\end{array}$ & $\begin{array}{l}-0.0175 \\
(-0.08)\end{array}$ \\
\hline Years of Military Service & & & & $\begin{array}{l}0.0342 \\
(1.43)\end{array}$ & $\begin{array}{l}0.0324 \\
(1.27)\end{array}$ \\
\hline Age & & & & & $\begin{array}{l}0.0006 \\
(0.04)\end{array}$ \\
\hline Married & & & & & $\begin{array}{l}0.7565 \\
(1.17)\end{array}$ \\
\hline Divorced & & & & & $\begin{array}{c}1.2369 * \\
(1.81)\end{array}$ \\
\hline \# of Daughters & & & & & $\begin{array}{l}0.0552 \\
(0.55)\end{array}$ \\
\hline \# of Sons & & & & & $\begin{array}{l}-0.0686 \\
(-0.69)\end{array}$ \\
\hline intercept & $\begin{array}{c}-1.4780^{* * *} \\
(-7.84)\end{array}$ & $\begin{array}{c}-1.3610^{* * *} \\
(-4.71)\end{array}$ & $\begin{array}{l}-0.8289 \\
(-0.97)\end{array}$ & $\begin{array}{c}-0.8396 \\
(-0.98)\end{array}$ & $\begin{array}{l}-1.7265 \\
(-1.47)\end{array}$ \\
\hline $\mathrm{N}$ & 638 & 598 & 598 & 598 & 598 \\
\hline
\end{tabular}

Robust standard errors used to report $t$ statistics in parentheses

${ }^{*} p<.10 * * p<.05 * * * p<.01$ 
Table 5: Logit Analysis of Scandal Type

\begin{tabular}{|c|c|c|c|}
\hline \multicolumn{4}{|c|}{ Dependent Variable: Any Scandals $(1,0)$} \\
\hline Mean of Each Variable & $\begin{array}{l}\text { All } \\
(1)\end{array}$ & $\begin{array}{c}\text { Financial } \\
(2)\end{array}$ & $\begin{array}{c}\text { Non-Financial } \\
\text { (3) }\end{array}$ \\
\hline Stock Allocation & $\begin{array}{c}0.7104^{* *} \\
(2.36)\end{array}$ & $\begin{array}{c}0.9493^{* * *} \\
(2.93)\end{array}$ & $\begin{array}{l}0.5436 \\
(1.14)\end{array}$ \\
\hline DW Nominate 1 & $\begin{array}{c}0.6559^{* * *} \\
(2.97)\end{array}$ & $\begin{array}{c}0.7990 * * * \\
(3.33)\end{array}$ & $\begin{array}{l}0.3989 \\
(1.13)\end{array}$ \\
\hline DW Nominate 2 & $\begin{array}{l}0.0137 \\
(0.05)\end{array}$ & $\begin{array}{l}0.0367 \\
(0.13)\end{array}$ & $\begin{array}{l}-0.3229 \\
(-0.90)\end{array}$ \\
\hline Member of House & $\begin{array}{c}-0.5626^{* *} \\
(-2.33)\end{array}$ & $\begin{array}{c}-0.6112^{* *} \\
(-2.38)\end{array}$ & $\begin{array}{l}-0.4998 \\
(-1.47)\end{array}$ \\
\hline Congressional Tenure & $\begin{array}{c}0.0254^{* *} \\
(2.33)\end{array}$ & $\begin{array}{c}0.0204^{*} \\
(1.77)\end{array}$ & $\begin{array}{l}0.0082 \\
(0.50)\end{array}$ \\
\hline Log Total Investments & $\begin{array}{c}-0.1691^{* * *} \\
(-4.63)\end{array}$ & $\begin{array}{c}-0.1581^{* * *} \\
(-4.31)\end{array}$ & $\begin{array}{c}-0.1301^{* * *} \\
(-2.73)\end{array}$ \\
\hline Log Total Assets & $\begin{array}{l}0.0995 \\
(1.27)\end{array}$ & $\begin{array}{l}0.0569 \\
(0.70)\end{array}$ & $\begin{array}{c}0.2202 * \\
(1.82)\end{array}$ \\
\hline Leverage & $\begin{array}{c}-0.0720 \\
(-1.39)\end{array}$ & $\begin{array}{c}-0.0480 \\
(-0.97)\end{array}$ & $\begin{array}{l}-0.0847 \\
(-0.62)\end{array}$ \\
\hline Log Total Debt & $\begin{array}{l}0.0246 \\
(1.28)\end{array}$ & $\begin{array}{l}0.0228 \\
(1.08)\end{array}$ & $\begin{array}{c}-0.0049 \\
(-0.18)\end{array}$ \\
\hline MBA Degree & $\begin{array}{l}0.1445 \\
(0.34)\end{array}$ & $\begin{array}{l}0.4733 \\
(1.10)\end{array}$ & $\begin{array}{c}-0.6431 \\
(-0.79)\end{array}$ \\
\hline Law Degree & $\begin{array}{l}-0.0175 \\
(-0.08)\end{array}$ & $\begin{array}{l}0.1818 \\
(0.82)\end{array}$ & $\begin{array}{l}-0.1469 \\
(-0.47)\end{array}$ \\
\hline Years of Military Service & $\begin{array}{l}0.0324 \\
(1.27)\end{array}$ & $\begin{array}{l}0.0173 \\
(0.60)\end{array}$ & $\begin{array}{l}0.0420 \\
(1.26)\end{array}$ \\
\hline Age & $\begin{array}{l}0.0006 \\
(0.04)\end{array}$ & $\begin{array}{l}0.0006 \\
(0.04)\end{array}$ & $\begin{array}{l}-0.0059 \\
(-0.29)\end{array}$ \\
\hline Married & $\begin{array}{l}0.7565 \\
(1.17)\end{array}$ & $\begin{array}{l}0.8456 \\
(1.18)\end{array}$ & $\begin{array}{l}0.7927 \\
(0.73)\end{array}$ \\
\hline Divorced & $\begin{array}{c}1.2369 * \\
(1.81)\end{array}$ & $\begin{array}{c}1.4752^{*} \\
(1.95)\end{array}$ & $\begin{array}{l}1.1551 \\
(1.04)\end{array}$ \\
\hline \# of Daughters & $\begin{array}{l}0.0552 \\
(0.55)\end{array}$ & $\begin{array}{l}0.0368 \\
(0.37)\end{array}$ & $\begin{array}{l}0.1097 \\
(0.62)\end{array}$ \\
\hline \# of Sons & $\begin{array}{c}-0.0686 \\
(-0.69)\end{array}$ & $\begin{array}{c}-0.1440 \\
(-1.34)\end{array}$ & $\begin{array}{l}-0.0256 \\
(-0.15)\end{array}$ \\
\hline intercept & $\begin{array}{c}-1.7265 \\
(-1.47)\end{array}$ & $\begin{array}{c}-1.7344 \\
(-1.37)\end{array}$ & $\begin{array}{c}-4.4672^{* *} \\
(-2.32)\end{array}$ \\
\hline $\mathrm{N}$ & 598 & 598 & 598 \\
\hline
\end{tabular}

Robust standard errors used to report $t$ statistics in parentheses

$$
{ }^{*} p<.10 * * p<.05 * * * p<.01
$$


Table 6: Summary Statistics for Lottery Experiment

\begin{tabular}{lccccc}
\hline Variable & Obs & Mean & Std. Dev. & Min & Max \\
\hline & & & & & \\
Choose B (x 100) & 101 & 72.77 & 15.50 & 40 & 100 \\
Downside Percent (x 100) & 101 & 4.18 & 2.37 & 2 & 9 \\
Portfolio Allocation & 101 & 0.45 & 0.16 & 0.07 & 1 \\
Portfolio Risk & 101 & 0.10 & 0.03 & 0.05 & 0.20 \\
& & & & & \\
\hline
\end{tabular}


Figure 2: Distribution of Lottery Choices

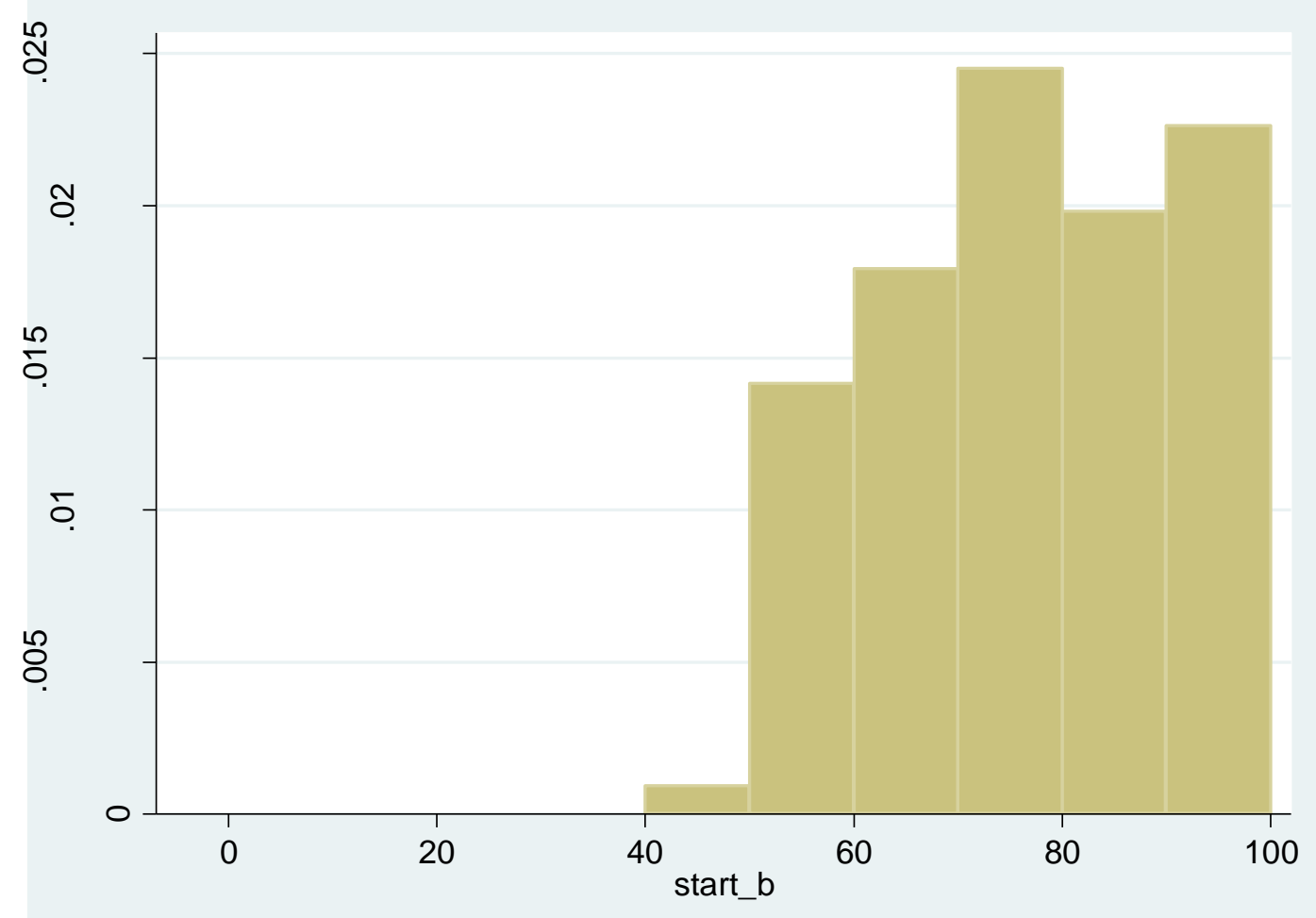


Table 7: Correlating Choices to High-Stakes Investment Choices

Dependent Variable: Measure of High-Stakes Investment Risk-Taking

\begin{tabular}{|c|c|c|c|c|}
\hline & $\begin{array}{c}\text { Portfolio } \\
\text { Allocation } \\
(1)\end{array}$ & $\begin{array}{c}\text { Portfolio } \\
\text { Allocation } \\
(2)\end{array}$ & $\begin{array}{c}\text { Portfolio } \\
\text { Risk } \\
(3) \\
\end{array}$ & $\begin{array}{c}\text { Portfolio } \\
\text { Risk } \\
(4) \\
\end{array}$ \\
\hline Choose B & $\begin{array}{c}-0.0025^{* * *} \\
(-2.78)\end{array}$ & & $\begin{array}{c}-0.0004^{* * *} \\
(-2.86)\end{array}$ & \\
\hline Downside Percent & & $\begin{array}{c}0.0182^{* * *} \\
(2.83)\end{array}$ & & $\begin{array}{c}0.0030 * * * \\
(2.72)\end{array}$ \\
\hline Intercept & $\begin{array}{c}0.6394^{* * *} \\
(8.93)\end{array}$ & $\begin{array}{c}0.3781^{* * *} \\
(11.33)\end{array}$ & $\begin{array}{c}0.1325^{* * *} \\
(10.67)\end{array}$ & $\begin{array}{c}0.0874 * * * \\
(15.70)\end{array}$ \\
\hline $\mathrm{N}$ & 101 & 101 & 101 & 101 \\
\hline$R-s q$ & 0.059 & 0.070 & 0.066 & 0.067 \\
\hline
\end{tabular}

Robust standard errors used to report t statistics in parentheses

$* p<.10 * * p<.05 * * * p<.01$ 